\section{Limitations of Science}

IN a paper "Methods of Research" (J. Univ. Bom. bay, 12, March 1944, and 13, March 1945), Prof. D. D. Kanga stresses the limitations of the scientific method in the modern world and the need for supplementing it, both in the world of affairs and in the sub-atomic world, by another training and discipline capable of transforming the present selfish, exploiting animal-man into a self-sacrificing, co-operating human being, willing to share with others. This technique Prof. Kanga terms the 'occult method', and emphasizing the importance of developing character, he believes that the chief drawback in our present system of education is the lopsided development of the individual. The university, he thinks, should address itself to this problem. In an earlier paper, "Knowledge Alone is not Enough to Solve our Problems" ( $J$. Univ. Bombay, 12, Part 3, November 1943), Prof. Kanga urged that it is the duty of a university to see that its curriculum provides for the development of its alumni equally from all sides; alongside science we require spiritual strength and spiritual qualities to enable us to resolve the many deadlocks confronting us in the world to-day.

\section{Pitfalls in Prehistory}

A SHORT paper by Prof. C. van Riet Lowe of Johannesburg (S. African J. Sci., 41, 345; 1945) deserves to be noted by prehistorians elsewhere. It describes remarkable instances of artefacts transferred to surprisingly deep deposits by torrential river action; flaked pebbles from Carboniferous glacial gravels, betrayed by glacial striations; neolithic celts dispersed by a Norwegian settler in the last century; a soda-water bottle under $20 \mathrm{ft}$. of river-gravel ; a wagon-wheel $23 \mathrm{ft}$. below a river bed, associated with a rolled palæolith; faked glass beads of German fabric, like those from Zimbabwe, reflecting a temporary fashion in amulets about 1908, and widely distributed in Transkei ; a stone Chinese Buddha in undisturbed soil along the route of the Voortrekkers of 1837 ; and more Roman coins to add to those already known from various parts of South Africa and Rhodesia. The writer ends with an appeal to settlers, travellers, and field-workers not to discard any worked objects in situations where their presence may mislead.

\section{Supernova in Canes}

THE June issue of Sky and. Telescope contains a short reference to the discovery of a supernova in N.G.C. 5195, a satellite of the famous Whirlpool galaxy $M$ 5l. M. L. Humason was observing this satellite for the first time in three years, and on April 6 he noticed a faint star with which he was not previously familiar. The following evening he obtained its spectrum, which confirmed his suspicions that it was a supernova. At the time of discovery it had passed maximum by about 65 days. On April 12 the nova was at magnitude 16 photographic and 14 photovisual ; its estimated maximum brightness was $11 \cdot 0$ photographic. It was fortunate that Humason had $M 51$ down on his observing programme on April 6, because the star was fading so rapidly that in a few weoks it would probably have been overlooked. A supernova appears in a spiral nebula on an average once in four hundred years, and this makes the coincidence all the more remarkable. In addition, the star would probably have escaped detection if it had not been so close to the central nucleus.

\section{The Night Sky in January}

NEw moon occurs on January 3d. 12h. 30m. U.T and full moon on January 17d. 14h. $46 \mathrm{~m}$. The follow ing conjunctions with the moon take place: Jan Id. 15h., Mercury $0.2^{\circ}$ N.; Jan. 17d. 04h., Satur $2^{\circ}$ S. ; Jan. 17d. 07h., Mars $2^{\circ}$ N. ; Jan. 24d. 11 h. Jupiter $4^{\circ} \mathrm{S}$. In addition to these conjunctions wit] the moon, Mars is in conjunction with Saturn or Jan. 22d. 17h., Mars being $4 \cdot 4^{\circ} \mathrm{N}$. Occultations o stars brighter than magnitude 6 are as follows Jan. 12d. 17h. 39.Im., $147 B$ Aries $(D)$; Jan. 14d 0lh. $57 \cdot 8 \mathrm{~m} ., 85 \mathrm{H}$ Tauri $(D)$; Jan. 24d. 06h. 10.4m., 80 Virgo $(R)$. The times are for Greenwich and $(D)$ and $(\boldsymbol{R})$ refer to disappearance and reappearance respectively. Mercury can be seen in the morning hours, rising at $6 \mathrm{~h} .25 \mathrm{~m}$. and $7 \mathrm{~h} .13 \mathrm{~m}$. at the beginning and middle of the month. Towards the end of the month the planet rises about the time of sunrise. Venus is too close to the sun during January for good observation, rising about 20 minutes before the sun on Jan. 1 and 15 minutes after the sun on Jan. 31. Mars, in the constellation of Cancer at the beginning of January, moving later into the constellation of Gemini, rises early in the evening and is well placed for observation throughout the night. The planet is in opposition with the sun on Jan. 14. Jupiter, in the constellation of Virgo, rises at $1 \mathrm{~h}$. $36 \mathrm{~m}$. on Jan. 1 and about midnight on Jan. 31. Saturn, in the constellation of Gemini, is visible throughout the night and does not set before the late morning hours. The earth makes its closest approach to the sun on Jan. 2. The Quadrantid meteor shower occurs during the first few nights of January.

\section{Announcements}

Prof. E. D. Hughes, professor of chemistry at the University College of North Wales, Bangor, will deliver the Tilden Lecture of the Chemical Society on January 17 at 5 p.m.

Mr. Paul G. 'Esprnasse has been appointed lecturer and head of the Department of Zoology in the University College of Hull.

Standard Telephones and Cables, Ltd., have formed a central laboratory organization to undertake long-term research and development in the telecommunication, electronies and allied fields. The new laboratories, to be known as Standard Telecommunication Laboratories, Ltd., will be housed at Progress Way, Great Cambridge Road, Enfield, pending the erection of suitable permanent premises. They will have as their principal objective the intensification of research and development in all aspects of telephony, telegraphy, electronics, cables, radio, television, etc., and the various divisions of the Laboratories will be under the direction of specialists in the different spheres.

A Conference on "The Needs and Problems of the Family", arranged under the joint auspices of the British Social Hygiene Council and the Town and Country Planning Association, will be held at British Medical Association House, London, during January 24-25. Further information can be obtained from the Secretary, British Social Hygiene Council, Tavistock House North, Tavistock Square, London, W.C.1.

Erratum.-Nature, November 24, p. 626, col. 2, par. "British Bryological Society": Dicranum strictum is a recent addition to the flora of Surrey, not Britain as printed. 